\title{
SIMULATION OF MAIZE GROWTH UNDER DIFFERENT SOWING TIMES AND DEFICIT IRRIGATION CONDITIONS
}

\author{
IMULATION OF MAIZE GROWTH UNDER DIFFERENT SOWING TIMES AND \\ DEFICIT IRRIGATION CONDITIONS
}

\author{
Fayaz AGHAYARI ${ }^{1}$; Farzad PAKNEJAD ${ }^{2}$; Mohammad Nabi ILKAEE ${ }^{2}$ \\ 1. Assistant Professor of Irrigation, Department of Agronomy, Karaj Branch, Islamic Azad University, Karaj, Iran. \\ aghayari_ir@yahoo.com; 2. Department of Agronomy, Karaj Branch, Islamic Azad University, Karaj, Iran.
}

\begin{abstract}
Simulation models of crops are referred as an efficient complement for the experimental study. Also crop simulation models can be useful for making appropriate decisions on agricultural systems. So this study aimed to simulate the growth of maize under different sowing times and deficit irrigation conditions, using the Decision Support System for Agrotechnology Transfer (DSSAT) model in 2014 year. This study was conducted in the research field of Islamic Azad University of Karaj in 2013 year. The experiment was designed in a split-block with four replications. Treatments included four sowing times of April 30 (S1), May 20 (S2), June 10 (S3), and June 27 (S4) in the main plots and three irrigation levels of $40 \%$ available water depletion (W1), 60\% available water depletion (W2), and 80\% available water depletion in the sub-plots. Root Mean Square Error (RMSE) of grain yield for all four sowing times on three levels of irrigation in Karaj region varied from 581.43 to $1,990.81 \mathrm{~kg}$ per hectare. It was also calculated the model efficiency coefficient (d) ranged 0.87-0.98 for the trait. The RMSE of the total dry matter was determined 861.88-2,173.66 kg per hectare; that was while $\mathrm{R}^{2}(1: 1)$ of total dry weight varied $0.89-0.98$. The results indicate that the model's ability to predict dry matter yield of maize is good enough.
\end{abstract}

KEYWORDS: Maize. CERES-Maize model. Yield. Simulation.

\section{INTRODUCTION}

Today, an important part of studies in agricultural sciences are aimed to find agricultural strategies reducing water use. The strategies allow plant environment and soil moisture to maintain maximum. Note that the yield of any crop in an environment depends mainly on irrigation, and so if the water would not be managed properly, it exposed the crop at risk of losses. Thus, there is significant interest in technologies that increase water use efficiency and consequently, production and productivity (SINGH et al., 2008). In arid and semi-arid areas, water shortage has always been one of the main constraints to agricultural development, and thus, improving water use efficiency is very important in these areas. In recent decades, many models to simulate crop growth and soil water management have been developed by researchers in the field of agriculture. The crop simulation models (CSMs) have been applied to study crops, including the selection of plant and cultivars suitable for planting, determining the best crop management, estimating regional production capacity, policy for breeding, research priority setting, technology transfer, agro-ecological classification and predicting the effects of climate change (SOLTANI; HOOGENBOOM, 2007).

CSM-CERES-Maize model is considered as the most widely used crop simulation models of daily growth of corn, and a part of the DSSAT software package, which is the result of more than 30 years worldwide research. CERES-Maize model might simulate the effects of plant species, plant density, weather, sowing time, and soil water and nitrogen on growth, development and grain yield (HOOGENBOOM et al., 1999). This model has been used in many studies, including evaluating the crop yield in the semi-arid Mediterranean climate (NOUNA et al., 2003), simulating nitrate leaching and water efficiency strategies (LOPEZ-CEDRON et al., 2008), and its strength and performance have been proven.

This is a relatively simple model, which simulates development, growth and yield of corn. After its first edition released in 1986, it has been faced with little changes in the model by different researchers, while it is proposed to present an integration of formal or informal versions of CERES - Maize (LOPEZ- CEDRON et al., 2008). In this field, it has been already applied the CERESMaize model for predicting the yield of dryland corn in the state of Delaware, US (QUIRING; LEGATES; 2008), RZWQM-CERES-Maize model to evaluate the production of hybrid maize (MA et al., 2006) and CSM-CERES-Maize model to predict sowing time and crop yield out of the growing season in a subtropical environment (SOLER et al., 2007). 
Further, Bert et al. (2007) studied the sensitivity of yields simulated by CERES - Maize to the uncertainty of soil properties and daily solar radiation. The performance of CERES-Maize model was evaluated in semi-arid Mediterranean climate during the two years under three soil water levels (normal irrigation and two drought stress regimes) (NOUNA et al., 2000). The results showed that the difference between simulated and observed values for maximum leaf area index, biomass and grain yield in the full-irrigation treatment was less than $10 \%$. However, in terms of water stress, the difference between simulated and observed values for indicators presented varied from $15 \%$ to $46 \%$. Paknejad et al. (2012) also examined the simulation of grain yield of five wheat varieties in drought stress conditions at the end of the season by CERES-Wheat model, and reported positive results. Nouna et al. (2000) suggested that the water stress functions of CERES-Maize model should be adjusted in accordance with the weather conditions under study. Asadi and Clemente (2003) evaluated the CERES-Maize model of DSSAT v3.5 to simulating nitrate leaching, crop yield and soil moisture capacity in humid climates. The results showed that the grain yield was overestimated at some treatments. Overall, the nitrogen absorption was simulated above the actual value, while the model determined the leached nitrogen and soil moisture lower. It was also concluded that nitrate leaching was underestimated due to poor drainage of the soil.

So this study aimed to simulate the growth of maize under different sowing times and deficit irrigation conditions, using the Decision Support System for Agrotechnology Transfer (DSSAT) model in 2014 year.

MATERIAL AND METHODS
The experiment was conducted in the research field (Mahdasht area) of Islamic Azad University of Karaj, Iran in 2014 year, located at $35^{\circ} 5^{\prime}$ latitude and $50^{\circ} 54^{\prime}$ longitude and an altitude of 1,313m. Mahdasht area of Karaj has a semi-arid climate with average annual precipitation of 243 $\mathrm{mm}$. With a $180-150$ and sometimes 200 days of drought, and cold-wet winters and hot-dry summer, the region is semi-arid (PAKNEJAD et al., 2014). The distribution of rainfall in this area is usually from late October to mid-spring. The experiment was conducted in a split-block design with four replications. Treatments included four sowing times of April 30 (S1), May 20 (S2), June 10 (S3), and June 27 (S4) in the main plots and three irrigation levels of $40 \%$ available water depletion (W1), $60 \%$ available water depletion (W2), and $80 \%$ available water depletion in the sub-plots. In total, it was implemented 12 treatments in four replications (48 plots). Each plot contained six rows with a length of $5 \mathrm{~m}$, and inter row spacing of $0.6 \mathrm{~m}$, where the plants were planted at the interval of $0.13 \mathrm{~m}(10$ plants per square meter). It was considered interspacing of $150 \mathrm{~cm}$ and $0.75 \mathrm{~m}$ respectively, for main plots and the subplots. The SC 704 corn cultivar was selected for the purpose of this study, which was seeded on 5/31/2014, and irrigated immediately. Urea fertilizer was applied in two stages (half of the 6-8 leaf stage and the rest at the emergence of male inflorescence (tassel)), with the amount of $140 \mathrm{~kg}$ per hectare in each plot, which was completely dispersed. For weed control, it was carried out weeding four times between and within the rows.

Soil physical parameters, including saturation water content, field capacity, permanent wilting point (PWP) and saturated soil hydraulic conductivity, were estimated by testing the soil at depths of 0 to $0.3 \mathrm{~m}$, and entered into the model (Table 1).

Table 1. The soil physical parameters

\begin{tabular}{cccccccc}
\hline $\begin{array}{c}\text { Saturation } \\
\text { Percentage } \\
\mathrm{cm}^{3} / \mathrm{cm}^{3}\end{array}$ & $\begin{array}{c}\text { Field } \\
\text { Capacity } \\
\mathrm{cm}^{3} / \mathrm{cm}^{3}\end{array}$ & $\begin{array}{c}\text { Permanent } \\
\text { wilting point } \\
(\mathrm{PWP}) \\
\mathrm{cm}^{3} / \mathrm{cm}^{3}\end{array}$ & $\begin{array}{c}\text { Hydraulic } \\
\text { Conductivity } \\
\mathrm{cm} \mathrm{day}^{-1}\end{array}$ & $\begin{array}{c}\text { Sand } \\
\text { Content } \\
\mathrm{kg} / \mathrm{kg}\end{array}$ & $\begin{array}{c}\text { Silt } \\
\text { Content } \\
\mathrm{kg} / \mathrm{kg}\end{array}$ & $\begin{array}{c}\text { Clay } \\
\text { Content } \\
\mathrm{kg} / \mathrm{kg}\end{array}$ & Texture \\
\hline 32 & 22 & 11 & 18.11 & 0.56 & 0.26 & 0.18 & $\begin{array}{c}\text { Sandy } \\
\text { loam }\end{array}$ \\
\hline
\end{tabular}

To determine the physical and chemical properties of soil, it was soil samples randomly taken at the depths of $0-0.3 \mathrm{~m}$ at 20 sites. Then, the samples were pooled into a single sample, which was transferred to the lab. The soil properties were determined as shown in Table 2. 
Table 2. The results of soil test

\begin{tabular}{ccccccc}
\hline $\begin{array}{c}\text { Total } \\
\text { Nitrogen } \\
\begin{array}{c}\text { Content } \\
\mathrm{N}(\mathrm{g} / \mathrm{kg})\end{array}\end{array}$ & $\begin{array}{c}\text { Available } \\
\text { Phosphorus } \\
\mathrm{P}(\mathrm{ppm})\end{array}$ & $\begin{array}{c}\text { Available } \\
\text { Potassium } \\
\mathrm{K}(\mathrm{ppm})\end{array}$ & $\begin{array}{c}\text { Organic } \\
\text { Carbon } \\
\mathrm{OC}(\mathrm{g} / \mathrm{kg})\end{array}$ & $\mathrm{pH}$ & $\begin{array}{c}\text { Salinity } \\
\mathrm{ds} / \mathrm{m}\end{array}$ & $\begin{array}{c}\mathrm{CaCo}_{3} \\
(\mathrm{~g} / \mathrm{kg})\end{array}$ \\
\hline 0.4 & 8 & 185 & 4 & 7.6 & 0.9 & 170 \\
\hline
\end{tabular}

DSSAT software needs to input the information related to weather, soil, crop management and cultivars. Before running the model, the inputs to the model are necessary.

Weather data: daily minimum and maximum temperatures, solar radiation and precipitation.

Soil data: Soil texture, soil structure, number and depth of soil layers, bulk density, nutrients, field capacity, wilting point, depth of root penetration, the electrical conductivity and $\mathrm{pH}$ of each layer.

Crop management: cultivar and types of spring or autumn, sowing time, sowing depth, inter row spacing, density, irrigation dates and amount.

Genetic Coefficients of Maize:

The model has been calibrated for different corn varieties in different regions of the world, and the genetic coefficients obtained is available in its database. To use the CERES-Maize model for Single-Cross (SC) 704 corn in a new area like Karaj city, it is necessary to initially estimate the genetic coefficients of this cultivar. So, the model was calibrated using six genetic coefficients, which were extracted using field data (Table 3 ).

With inputs, the model performs the calculations from sowing to maturity, while simulating phonological stages, accumulation and partitioning the dry matter (DM), leaf area index (LAI), growth of the root, stem, leaves, and seeds, and also soil moisture and nitrogen contents, the water and nitrogen use of plant and the effect of water stress on plant growth and development.

Table 3. The genetic coefficients obtained for SC 704 grain maize

\begin{tabular}{ccccccc}
\hline $\begin{array}{c}\text { Maize } \\
\text { Variety }\end{array}$ & P1 & P2 & P5 & G2 & G3 & PHINT \\
\hline SC 704 & 236 & 0.400 & 790 & 833 & 8.5 & 55 \\
\hline
\end{tabular}

P1: Growing Degree Days (GDD) (based on the basic temperature of $8^{\circ} \mathrm{C}$ ) from seedling emergence to end of juvenile phase (days ${ }^{\circ} \mathrm{C}$ ), P2: photoperiod sensitivity coefficient (day per hour), P5: photoperiod from silking stage to physiological maturity $\left({ }^{\circ} \mathrm{C}\right)$, G2: maximum kernel number (kernels/plant), G3: the potential kernel growth rate at grain filling stage (mg per day), and PHINT: interval between the emergence of two successive leaves $\left({ }^{\circ} \mathrm{C}\right)$

Comparison of observed and simulated date:

To evaluate the model, predicted yield was evaluated by calculating the agreement index "d"

$d=1-\frac{\sum_{i=1}^{n}\left(P_{i}-O_{i}\right)^{2}}{\sum_{i=1}^{n}\left(\left|P_{i}-O_{i_{a r g}}\right|+O_{i}-O_{i_{m g g}} \mid\right)^{2}}$

$R^{2}=\frac{\sum_{i=1}^{n}\left(P_{i}-O_{i_{a g s}}\right)^{2}}{\sum_{i=1}^{n}\left(O_{i}-O_{i_{a v g}}\right)^{2}}$

$R M S E=\left[\frac{1}{n} \sum_{i=1}^{n}\left(P_{i}-O_{i}\right)^{2}\right]^{0.5}$
(Willmott, 1982), coefficient of determination $\left(\mathrm{R}^{2}\right)$ and root mean square error (RMSE). These measures of model accuracy are defined as follows:

where $\mathrm{P}_{\mathrm{i}}$ and $\mathrm{O}_{\mathrm{i}}$ are the predicted and observed values for the data pair, respectively, $\mathrm{n}$ is the number of observation, and $\mathrm{O}_{\text {iavg }}$ is the average of the observed values.

\section{RESULTS}

The coefficient of determination $\left(\mathrm{R}^{2}\right)$, which was obtained by the linear regression analysis of the functions between measured and simulated values of biomass for the maize, ranged 0.95-0.98, which indicates the accuracy of the model to simulate the crop biomass at the second sowing time (May 20). 
In the Karaj region, simulated biomass trends of all four sowing times by CERES-Maize model (Table 4) with the model efficiency coefficient (d) varied 0.85-0.98 shows that the model successfully predicted the biomass variation under the irrigation. Further, the coefficient of determination $\left(\mathrm{R}^{2}\right)$, which was obtained by the linear regression analysis of the functions between measured and simulated values of biomass for the maize, ranged 0.87-0.98, which indicates the accuracy of the model to simulate the crop biomass at the first sowing time (April 30). As indicated in Table 4, the model was good at evaluating the biomass production trend of all four sowing times, while the RMSE was calculated respectively 945-1,709, 861-1,872, 969-2,173, and $867-1,809 \mathrm{~kg}$ per hectare. However, RMSE was less than $20 \%$ of the average observed data in each sowing times. Bannayan et al. (2003) reported the yield with RMSE of 3.2 close to $20 \%$ of the average observed data (1.76 tons per hectare).

Table 4. The simulation results of biomass (kg/ha) at four sowing times and three irrigation levels

\begin{tabular}{ccccccc}
\hline Planting Dates & $\begin{array}{c}\text { Irrigation } \\
\text { Level }\end{array}$ & $\begin{array}{c}\mathrm{O}_{\mathrm{i}} \\
(\mathrm{kg} / \mathrm{ha})\end{array}$ & $\begin{array}{c}\mathrm{P}_{\mathrm{i}} \\
(\mathrm{kg} / \mathrm{ha})\end{array}$ & $\mathrm{d}$ & $\mathrm{R}^{2}$ & $\begin{array}{c}\mathrm{RMSE} \\
(\mathrm{kg} / \mathrm{ha})\end{array}$ \\
\hline \multirow{2}{*}{ April 30 } & $\mathrm{W} 1$ & 8,686 & 7,211 & 0.92 & 0.94 & 986.81 \\
(S1) & $\mathrm{W} 2$ & 7,071 & 7,617 & 0.98 & 0.95 & 945.91 \\
& $\mathrm{~W} 3$ & 4,572 & 6,965 & 0.87 & 0.90 & $1,709.94$ \\
\hline \multirow{2}{*}{ May 20 } & $\mathrm{W} 1$ & 13,057 & 11,375 & 0.90 & 0.95 & $1,872.22$ \\
(S2) & $\mathrm{W} 2$ & 7,801 & 8,443 & 0.98 & 0.98 & 861.88 \\
& $\mathrm{~W} 3$ & 5,599 & 6,465 & 0.93 & 0.95 & 916.82 \\
\hline \multirow{2}{*}{ June 10 } & $\mathrm{W} 1$ & 9,457 & 8,472 & 0.90 & 0.96 & $1,007.14$ \\
(S3) & $\mathrm{W} 2$ & 6,827 & 6,389 & 0.98 & 0.96 & 969.75 \\
& $\mathrm{~W} 3$ & 5,004 & 7,221 & 0.85 & 0.89 & $2,173.66$ \\
\hline \multirow{2}{*}{ June 27 } & $\mathrm{W} 1$ & 8,020 & 7,589 & 0.91 & 0.95 & $1,809.19$ \\
(S4) & $\mathrm{W} 2$ & 5,442 & 5,827 & 0.98 & 0.94 & 867.46 \\
& $\mathrm{~W} 3$ & 4,982 & 6,737 & 0.90 & 0.95 & 953.53 \\
\hline
\end{tabular}

$\mathrm{Pi}$ and Oi: Predicted and Observed Values, d: Willmott's index of agreement, $\mathrm{R}^{2}$ : Coefficient of Determination, and RMSE: Root-MeanSquare-Error

As shown in Table 5, in the first sowing time (April 30), the root mean square error (RMSE) of grain yield varied 869-1,003.5, while the model efficiency coefficient (d) has ranged 0.87-0.93. The highest model efficiency coefficient was calculated 0.98, and RMSE was determined 581 for the sowing time of May 20 with the irrigation level 2. In fact, the model predicated the grain yield of this treatment with the highest accuracy. As shown in Table 5, it is generally found that the model simulated the grain yield with acceptable accuracy for the four sowing times. Lowest accuracy was associated with the simulation of grain yield for the sowing time of May 20 with the irrigation level 1. The RMSE and $\mathrm{d}$ of this treatment were determined respectively, $1,990.8$ and 0.79 . In general, the coefficient of determination varied $0.85-0.98$ for all cultivars at four sowing times, indicating that there was an acceptable correlation between simulated and measured values of the trait in the Karaj region. The model, which was assessed at four sowing times, the RMSE of grain yield ranged 599-1,990.5 $\mathrm{kg}$ per hectare. This was less than $20 \%$ of the average observed data.

Timsina et al. (2006) suggested that the simulation of crop growth by CERES-Wheat model under no nitrogen and water stress in semi-humid regions of India, Nepal, Bangladesh and Australia led to the yield variation coefficient ranged $7 \%$ 17\%. Ghaffari et al. (2001) evaluated different management strategies and determined optimal strategies using CERES-Wheat model. They reported that the grain yield was simulated between 6.9-7.8 tons per hectare depending on the different strategies, while and difference between simulated and observed values was 0.24 tons per hectare (which was less than $10 \%$ of the average observed yields). Further, they predicated the yield in six regions by the model CERES-Wheat model, and showed that wheat yield varied $8,985-9,884 \mathrm{~kg}$ per hectare depending on the region in different years. 
Table 5. The simulation results of grain yield $(\mathrm{kg} / \mathrm{ha})$ at four sowing times and three irrigation levels

\begin{tabular}{ccccccc}
\hline Planting Dates & $\begin{array}{c}\text { Irrigation } \\
\text { Level }\end{array}$ & $\begin{array}{c}\mathrm{O}_{\mathrm{i}} \\
(\mathrm{kg} / \mathrm{ha})\end{array}$ & $\begin{array}{c}\mathrm{P}_{\mathrm{i}} \\
(\mathrm{kg} / \mathrm{ha})\end{array}$ & $\mathrm{d}$ & $\mathrm{R}^{2}$ & $\begin{array}{c}\mathrm{RMSE} \\
(\mathrm{kg} / \mathrm{ha})\end{array}$ \\
\hline \multirow{2}{*}{ April 30 } & $\mathrm{W} 1$ & 3,817 & 2,007 & 0.91 & 0.90 & 869.074 \\
(S1) & $\mathrm{W} 2$ & 2,113 & 2,618 & 0.93 & 0.86 & 941.641 \\
& $\mathrm{~W} 3$ & 1,737 & 2,742 & 0.87 & 0.86 & $1,003.514$ \\
\hline \multirow{2}{*}{ May 20 } & $\mathrm{W} 1$ & 7,121 & 5,684 & 0.79 & 0.85 & $1,990.808$ \\
(S2) & $\mathrm{W} 2$ & 3,067 & 2,642 & 0.98 & 0.98 & 581.429 \\
& $\mathrm{~W} 3$ & 2,669 & 3,119 & 0.97 & 0.97 & 671.983 \\
\hline \multirow{2}{*}{ June 10 } & $\mathrm{W} 1$ & 5,144 & 4,033 & 0.86 & 0.84 & $1,036.531$ \\
(S3) & W2 & 3,200 & 2,879 & 0.92 & 0.93 & 770.575 \\
& $\mathrm{~W} 3$ & 1,527 & 2,562 & 0.85 & 0.91 & 916.496 \\
\hline \multirow{2}{*}{ June 27 } & $\mathrm{W} 1$ & 3,819 & 3,380 & 0.90 & 0.91 & 599.2361 \\
(S4) & W2 & 2,141 & 2,400 & 0.92 & 0.90 & 946.353 \\
& W3 & 1,807 & 1,499 & 0.90 & 0.91 & 613.001 \\
\hline
\end{tabular}

Pi and Oi: Predicted and Observed Values, d: Willmott's index of agreement, $\mathrm{R}^{2}$ : Coefficient of Determination, and RMSE: Root-MeanSquare-Error

As shown in Table 6, in the first sowing time (April 30), the root mean square error (RMSE) of leaf area index varied 869-1,003.5, while the model efficiency coefficient (d) was determined 0.94-0.98. Further, the coefficient of determination $\left(\mathrm{R}^{2}\right)$, which was obtained by the linear regression analysis of the functions between measured and simulated values of leaf area index for the maize, ranged 0.84-0.94, which indicates the accuracy of the model to simulate the leaf area index at four sowing times. Although there was low correlation in some treatments, like sowing time of 6/24/2014 with irrigation level 3 (0.87), but the model simulated accurately the variation of leaf area index. In the
Karaj region, simulated leaf area index trends of all four sowing times by CERES-Maize model (Table 6) with the model efficiency coefficient (d) varied 0.89-0.98 shows that the model successfully predicted the leaf area index variation. In addition, the RMSE value was equal to $35 \%$ of the average observed data. This is consistent with Arora et al. (2007), who determined RMSE value of $0.5 \mathrm{~m}^{2} / \mathrm{m}^{2}$ with $35 \%$ of the average observed data and correlation coefficient of 0.88 associated with the simulation of wheat's leaf area index during the growing season.

Table 6. The simulation results of leaf area index $(\mathrm{kg} / \mathrm{ha})$ at four sowing times and three irrigation levels

\begin{tabular}{ccccccc}
\hline Planting Dates & $\begin{array}{c}\text { Irrigation } \\
\text { Level }\end{array}$ & $\begin{array}{c}\mathrm{O}_{\mathrm{i}} \\
(\mathrm{kg} / \mathrm{ha})\end{array}$ & $\begin{array}{c}\mathrm{P}_{\mathrm{i}} \\
(\mathrm{kg} / \mathrm{ha})\end{array}$ & $\mathrm{d}$ & $\mathrm{R}^{2}$ & $\begin{array}{c}\mathrm{RMSE} \\
(\mathrm{kg} / \mathrm{ha})\end{array}$ \\
\hline \multirow{2}{*}{ April 30 } & $\mathrm{W} 1$ & 3.21 & 2.81 & 0.96 & 0.92 & 0.686 \\
(S1) & $\mathrm{W} 2$ & 3.12 & 3.21 & 0.944 & 0.83 & 0.823 \\
& $\mathrm{~W} 3$ & 2.73 & 2.75 & 0.981 & 0.94 & 0.518 \\
\hline \multirow{2}{*}{ May 20 } & $\mathrm{W} 1$ & 3.16 & 3.37 & 0.957 & 0.92 & 0.791 \\
(S2) & $\mathrm{W} 2$ & 3.15 & 3.56 & 0.964 & 0.93 & 0.836 \\
& $\mathrm{~W} 3$ & 3.53 & 3.17 & 0.898 & 0.87 & 1.126 \\
\hline \multirow{2}{*}{ June 10 } & $\mathrm{W} 1$ & 3.62 & 3.26 & 0.96 & 0.9 & 0.86 \\
(S3) & $\mathrm{W} 2$ & 3.1 & 3.59 & 0.948 & 0.86 & 0.847 \\
& $\mathrm{~W} 3$ & 2.94 & 3.44 & 0.951 & 0.87 & 0.837 \\
\hline \multirow{2}{*}{ June 27 } & $\mathrm{W} 1$ & 3.15 & 3.55 & 0.961 & 0.91 & 0.785 \\
(S4) & $\mathrm{W} 2$ & 3.12 & 3.71 & 0.93 & 0.84 & 1.06 \\
& $\mathrm{~W} 3$ & 2.58 & 3.46 & 0.935 & 0.87 & 1.09 \\
\hline
\end{tabular}

Pi and Oi: Predicted and Observed Values, d: Willmott's index of agreement, $\mathrm{R}^{2}$ : Coefficient of Determination, and RMSE: Root-MeanSquare-Error

The simulated and observed LAIs show different distribution (Table 6). This deviation might be caused by the difference between dates of model and measurement, as the leaf area index simulated by the model was exactly recorded at the pollination, while it was measured one or several days later or sooner in the field. In other side, such deviation might be result of inaccuracy in the measurement of leaf area index by the laboratory. In fact, when the leaves are yellow or folded, the 
light would pass their edges, which leads to an error in measuring the leaf area index. These reasons, and probably the method used in the model to simulate the leaf area index might lead the lack of higher accuracy of the model to predict LAI during pollination.

As shown in Table 7, in the second sowing time (May 20), the root mean square error (RMSE) of harvest index varied 0.066-0.086, while the model efficiency coefficient (d) ranged 0.90-0.97. The highest $d$ and lowest RMSE values were calculated respectively, 0.99 and 0.015 for the sowing time of May 20 with the Irrigation level 2. Additionally, the coefficient of determination $\left(\mathrm{R}^{2}\right)$, which was obtained by the linear regression analysis of the functions between measured and simulated values of harvest index for the maize, ranged $0.78-0.99$, which indicates the accuracy of the model to simulate the harvest index at four sowing times. In the Karaj region, simulated harvest index trends of all four sowing times by CERES-Maize model (Table 7) with the model efficiency coefficient (d) of various cultivars varied 0.82-0.99 shows that the model successfully predicted the harvest index variation, while it simulated accurately the harvest index variation even with a low coefficient of determination. Note that the lowest accuracy of simulation was associated with the treatment of fourth sowing time (2014/6/27) and irrigation level 1. In addition, the RMSE and coefficient of determination values were calculated respectively, 0.186 and $0.78 \%$, meaning that the simulation accuracy of this treatment was lower than others, which could be referred to the model's inability to simulate the harvest index.

Table 7. The simulation results of harvest index $(\mathrm{kg} / \mathrm{ha})$ at four sowing times and three irrigation levels

\begin{tabular}{ccccccc}
\hline Planting Dates & $\begin{array}{c}\text { Irrigation } \\
\text { Level }\end{array}$ & $\begin{array}{c}\mathrm{O}_{\mathrm{i}} \\
(\mathrm{kg} / \mathrm{ha})\end{array}$ & $\begin{array}{c}\mathrm{P}_{\mathrm{i}} \\
(\mathrm{kg} / \mathrm{ha})\end{array}$ & $\mathrm{d}$ & $\mathrm{R}^{2}$ & $\begin{array}{c}\mathrm{RMSE} \\
(\mathrm{kg} / \mathrm{ha})\end{array}$ \\
\hline \multirow{2}{*}{ April 30 } & $\mathrm{W} 1$ & 0.223 & 0.177 & 0.90 & 0.74 & 0.086 \\
(S1) & $\mathrm{W} 2$ & 0.231 & 0.214 & 0.97 & 0.92 & 0.066 \\
& $\mathrm{~W} 3$ & 0.253 & 0.214 & 0.95 & 0.88 & 0.08 \\
\hline \multirow{2}{*}{ May 20 } & $\mathrm{W} 1$ & 0.27 & 0.183 & 0.93 & 0.97 & 0.104 \\
(S2) & $\mathrm{W} 2$ & 0.198 & 0.183 & 0.99 & 0.99 & 0.015 \\
& $\mathrm{~W} 3$ & 0.341 & 0.234 & 0.91 & 0.98 & 0.116 \\
\hline \multirow{2}{*}{ June 10 } & $\mathrm{W} 1$ & 0.341 & 0.105 & 0.91 & 0.86 & 0.177 \\
(S3) & W2 & 0.198 & 0.125 & 0.84 & 0.85 & 0.118 \\
& $\mathrm{~W} 3$ & 0.202 & 0.119 & 0.85 & 0.8 & 0.208 \\
\hline \multirow{2}{*}{ June 27 } & W1 & 0.27 & 0.145 & 0.87 & 0.78 & 0.186 \\
(S4) & W2 & 0.223 & 0.157 & 0.88 & 0.90 & 0.107 \\
& W3 & 0.231 & 0.129 & 0.82 & 0.86 & 0.112
\end{tabular}

Pi and Oi: Predicted and Observed Values, d: Willmott's index of agreement, $\mathrm{R}^{2}$ : Coefficient of Determination, and RMSE: Root-MeanSquare-Error

\section{DISCUSSION}

At first, this study provides a satisfactory calibration of the model applied to different water levels and sowing times. Other authors also calibrated the CERES-Maize model for conventional local varieties under full-irrigation (NOUNA et al., 2000), or evaluated only different levels of nitrogen fertilizer (ASADI; CLEMENTE, 2003). The present study compares the RMSE and $r^{2}$ values associated with SC 704 maize. Table 3 shows the genetic coefficients of SC 704, obtained by GENCALC application. In an extensive research on corn in different regions of the world, the genetic coefficients of maize have been calculated in different ranges, as follows: $\mathrm{P} 1: 100-400^{\circ} \mathrm{C} /$ day; P2: 0-4 hr/day; P5: 600-900 GDD; PHINT: 45-55 GDD at each leaf emergence; G2: max. 1,000 grains weight; and G3: 5-12 mg. GENCALC is an effective tool to determine the plant genetic coefficients, especially when the number of treatments used to calibrate the model is high. It is more efficient, more accurate, and time-saving in calibration. In general, the model evaluated accurately the different irrigation levels and sowing times; that is while, with the genetic coefficients presented in this study, it was successfully used to determine various ware management strategies and sowing times for SC 704 maize in the Karaj region. Panda et al. (2004) studied the effects of drought stress on maize. They suggested that the CERESMaize model efficiently simulate the corn grain yield and dry matter.

Also, Yang et al. (2009) applied the CERES-Maize model on 49 different hybrids in North Carolina. He found that the model simulated 
grain yield accurately. However, Nouna et al. (2000) reported that the CERES-Maize model did not provide satisfactory results in predicting leaf area index, biomass and crop yield under soil water stress in semi-arid Mediterranean climate. Xevi et al. (1996) suggested that the CERES-Maize model simulated the soil water content, leaf area index, and biomass above ground level with confidence of $95 \%$ compared to observed field data. Carberry (1991) noted that the CERES-Maize model might simulate the yield under normal conditions, but it would provide higher performance for simulating the period (days) during tasseling to physiological maturity for corn compared to the number of days from germination to the final stage of germination, and grain yield.

Ghaffari et al. (2001) evaluated the optimal management strategies using CERES-Wheat model. He reported that the grain yield varied 6.9-7.8 tons per hectare depending on the different strategies, while the difference between simulated and measured values was determined 0.24 tons per hectare (less than $10 \%$ of the average observed yields). They also used the CERES-Wheat model to predict yield potential of six areas predicted. Later, they reported that wheat yield depending on the region varied 8,985-9,884 $\mathrm{kg}$ per hectare during different years.

The simulated and measured dry matter accumulation were similar, which indicates a high correlation between the two variables of leaf area index and dry matter accumulation. A study by Singh et al. (2008) evaluated CERES-Wheat model to simulate biomass under different treatments of fertilizer and irrigation regimes, he reported that there was calculated RMSE value of $1,940 \mathrm{~kg}$ per hectare between observed and simulated biomass at the maturity stage.

The reduced simulation accuracy might be due to lack of potential conditions during growing phase, measurement errors, and lack of relevance between the values of model-defined parameters and studied region. Therefore, it is necessary to manage and reduce the error factors. However, the model overestimated dry matter in some cases, and underestimated it in some other cases, though the differences were acceptable. In general, the model simulated dry matter production at an acceptable level. The results indicate that LAI was overestimated, perhaps because there were some constraints in the field, which were inputted in the model; that was while the leaf area index was simulated below the observed values at early stages of the growth. In addition, such error might be resulted from the lack of accuracy during measurement of LAI by the Lab. In fact, when the leaves are yellow or folded, the light would pass their edges, which leads to an error in measuring the leaf area index. In general, a model's ability to predict variation in leaf area index is important, and in turn, to estimate the amount of radiation received, and dry matter production. It is also needed to determine the ratio of evaporation to evapotranspiration (SOLTANI et al., 2006).

The results indicate that the model's ability to predict dry matter yield of maize is good enough.

RESUMO: Os modelos de simulação de culturas são referidos como um complemento eficaz para o estudo experimental. Os modelos de simulação de culturas também podem ser úteis para a tomada de decisões adequadas em sistemas agrícolas. Portanto, este estudo teve como objetivo simular o crescimento do milho sob diferentes épocas de semeadura e condições de déficit de irrigação, utilizando o Sistema de Apoio à Decisão para o modelo de Transferência de Agrotecnologia (DSSAT) no ano de 2014. Este estudo foi realizado no campo experimental da Islâmica Azad Universidade de Karaj no ano de 2013. O experimento foi desenvolvido com delineamento em faixas com 4 repetições. Os tratamentos incluíram quatro épocas de semeaduras de 30 de Abril (S1), 20 de maio (S2), 10 de junho (S3), e 27 de junho (S4) nas parcelas principais e três níveis de irrigação de esgotamento de 40\% de água disponível (W1), 60\% depleção de água disponível (W2), e 80\% esgotamento da água disponível nos sub-parcelas. O erro da raiz do quadrado médio (RMSE) do rendimento de grãos para todas as quatro épocas de semeadura nos três níveis de irrigação na região Karaj variou de 581,43 a 1,990,81 kg por hectare. Também foi calculado o coeficiente de eficiência do modelo (d) que variou de 0,87 a 0,98 para a característica. O RMSE da matéria seca total foi determinada entre 861.88 e 2,173.66 kg por hectare; enquanto $\mathrm{R}^{2}(1: 1)$ da massa total variou de 0,89 a 0,98 . Os resultados indicam que a capacidade do modelo para prever a produção de matéria seca de milho é suficientemente boa.

PALAVRAS-CHAVE: Milho. CERES-Maize model. Produtividade. Simulação. 


\section{REFERENCES}

ARORA, V. K.; SINGH, H.; SINGH, B. Analyzing wheat productivity responses to climatic, irrigation and fertilizer-nitrogen regimes in a semi-arid sub-tropical environment using the CERES-Wheat model. Agric. water Manage, v. 94, p. 22-30, 2007. http://dx.doi.org/10.1016/j.agwat.2007.07.002

ASADI, M. E.; CLEMENTE, R. S. Evaluation of CERES-Maize of DSSAT model to simulate nitrate leaching, yield and soil moisture content tropical condition. Journal of food, Agriculture \& Environment (JFAE), v. 1, n. 3-4, p. 270-276, 2003.

BANNAYAN, M.; CROUT, N. M. J.; HOOGENBOOM, G. Application of the CERES- wheat model for within season prediction of winter wheat yields in the United Kingdom. Agron. J., v. 95, p. 114-125, 2003. http://dx.doi.org/10.2134/agronj2003.0114

BERT, F. E.; LACIANA, C. E.; PODESTÁ, G. P.; SATORRE, E. H.; MENÉNDEZ, A.N. Sensitivity of CERES-Maize simulated yields to uncertainty in soil properties and daily solar radiation. Agricultural Systems, v. 94, p. 141-150, 2007. http://dx.doi.org/10.1016/j.agsy.2006.08.003

CARBERRY, P. S. Test of leaf-area development in CERES-Maize: a correction. Field Crops Res. v. 27, p. 159-167, 1991. http://dx.doi.org/10.1016/0378-4290(91)90028-T

GHAFFARI, A.; COOK, H. F.; LEE, H. C. Simulating winter wheat yields under temperate conditions: exploring different management scenarios. Eur. J. Agron., v. 15, p. 231-240, 2001.

http://dx.doi.org/10.1016/S1161-0301(01)00111-3

HOOGENBOOM, G.; WILKENS, P. W.; THORNTON, P. K.; JONES, J. W.; HUNTL, A.; IMAMURA, D. T. Decision support system for argrotechnology transfer v3.5, DSSAT version3, Vol. 4. University of Hawaii. Honolulu, HI, 1999.

LOPEZ-CEDRON, F. X.; BOOT, K. J.; PINEIRO, J.; SAU, F. Improving the CERES-Maize model ability to simulate water deficit impact on maize production yield components. Agronomy, v. 100, p. 297-307, 2008. http://dx.doi.org/10.2134/agrojnl2007.0088

MA, L.; HOOGENBOOM, G.; AHUJA, L. R.; ASCOUGH, J. C.; SANSEENDRAN, S. A. Evaluation of the RZWQM-CERES-Maize hybrid model for maize production. Agricultural Systems, v. 87, p. 274-295, 2006. http://dx.doi.org/10.1016/j.agsy.2005.02.001

NOUNA, B. B.; KATERJI, N.; MASTORILLI, M. Using the CERES-Maize model in semi-arid mediterranen environment. Evaluation of model performance. European Journal of Agronomy, v. 13, p. 309-322, 2000. http://dx.doi.org/10.1016/S1161-0301(00)00063-0

NOUNA, B. B.; KATERJI, N.; MASTORILLI, M. Using the CERES-Maize model in semi-arid mediterranen environment: New modeling of leaf area and water stress functions. European Journal of Agronomy, v. 19, p. 115-123, 2003. http://dx.doi.org/10.1016/S1161-0301(02)00023-0

PAKNEJAD, F.; FAKHR, F. M.; MIRTAHERI, S. M. Validation of the Ceres-Wheat for Prediction of Wheat Varieties in Irrigation and Terminal Drought Stress. American Journal of Agricultural and Biological Science, v. 7, p. 180-185, 2012.

PAKNEJAD, F.; ILKAEE, M. N.; AMIRI, E.; ZAVAREH, M.; ARDAKANI, M. R.; KASHANI, A.; MIRTAHERI, S.M. Use of CROPGRO-soybean to simulate biomass and grain yield of soybean (Glycine max L.) in different planting dates. Journal of Biodiversity and Environmental Sciences. v. 4, p. 9-16, 2014. http://dx.doi.org/10.3844/ajabssp.2012.180.185 
PANDA, R, K.; BEHERA, S. K.; KASHYAP, P. S. Effective management of irrigation water for maize under stressed conditions. Agricultural Water Management, v. 66, p. 181-203, 2004.

http://dx.doi.org/10.1016/j.agwat.2003.12.001

QUIRING, S. M.; LEGATES, D. R. Application of CERES-Maize for within-season prediction of rainfed corn yields in Delaware, USA. Agricultural and Forest Meteorology, v. 149, p. 964-975, 2008.

http://dx.doi.org/10.1016/j.agrformet.2008.01.009

SINGH, A. K.; TRIPATHY, R.; CHOPRA, U. K. Evaluation of CERES-Wheat and CropSyst models for water-nitrogen interactions in wheat crop. Agric Water Manag. v. 95, p. 776 - 786, 2008.

http://dx.doi.org/10.1016/j.agwat.2008.02.006

SOLER, C. M. T.; SENTELHAS, P. C.; HOOGENBOOM, G. Application of the CSM-CERES-Maize model for planting data evaluation and yield forecasting for maize grown off-season in subtropical environment. European Journal Agronomy. v. 27, p. 165-177, 2007. http://dx.doi.org/10.1016/j.eja.2007.03.002

SOLTANI, A.; ROBERTSON, M. J.; MOHAMMAD-NEJAD, Y.; RAHEMI-KARIZAKI, A. Modeling chickpea growth and development: leaf production and senescence. Field Crops Res. v. 99, p. 14-23., 2006. http://dx.doi.org/10.1016/j.fcr.2006.02.006

http://dx.doi.org/10.1016/j.fcr.2006.02.005

http://dx.doi.org/10.1016/j.fcr.2006.02.004

Soltani, A.; Hoogenboom, G. Assessing crop management with crop simulation models based on generated weather data. Field crop Res. v. 103, p. 198-207, 2007.

TIMSINA, J.; HUMPHREYS, E. Performance of CERES-Rice and CERES-Wheat models in rice-wheat systems: A review, Agricultural Systems, v. 90, p. 5-31, 2006. http://dx.doi.org/10.1016/j.agsy.2005.11.007

WILLMOTT, C. J. Some comments on the evaluation of model performance. Bulletin of American

Meteorology Society, v. 63, p. 1309-1313, 1982. http://dx.doi.org/10.1175/1520-

0477(1982)063<1309:SCOTEO >2.0.CO;2

XEVI, E.; GILLEY, J.; FEYEN, J. Comparative study of two crop yield simulation models. Agric. Water Manage, v. 30, 155- 173, 1996. http://dx.doi.org/10.1016/0378-3774(95)01218-4

YANG, Z.; WILARKSON, G. G.; BUOL, G. S.; HEINGER, R. W. Estimating Genetic Coefficients for the CSM-CERES-Maize model in North Carolina environments. Agronomy Journal, v. 101, p. 1276-1285, 2009. http://dx.doi.org/10.2134/agronj2008.0234x 